\title{
Legal Protection of the Environment in Indonesia from a Green Victimology Perspective
}

\author{
Rani Hendriana ${ }^{1}$, \\ ${ }^{1}$ Jenderal Soedirman University \\ Purwokerto, Indonesia \\ ranihendriana27@gmail.com
}

\begin{abstract}
The portrait of legal protection for the environment so far has not been oriented to the needs of the environment itself as a victim. As a result, the responsibility of perpetrators of environmental crimes has not been aimed at recovering the damage caused. This study aims to determine the legal protection against environmental damage from the perspective of green victimology. This research was conducted using a normative juridical approach, with a statutory and conceptual approach. The conclusion of this study is that the legal protection of the environment from the perspective of green victimology seeks to place the environment as a victim. Therefore, it is necessary to base it on two aspects of protection, namely preventive and repressive protection. Preventive protection emphasizes the prevention aspect so that an educational approach is needed, there is a need for a monitoring system for potential activities at the community level, to the reconstruction of criminal law, namely the expansion of the principle of strict liability in environmental crimes and placing recovery as the main criminal sanction. Meanwhile, repressive protection emphasizes efforts to take action against damage through strengthening the synergy of law enforcement officers, which are oriented towards restoring environmental damage.
\end{abstract}

Keywords- Legal Protection, Environment, Green Victimology.

\section{INTRODUCTION}

A good environment is a human right of every Indonesian citizen, as mandated in the Indonesian constitution in Article 28H of the 1945 [1]. This provision is a form of guarantee of legal protection for citizens to get a good and healthy environment. In fact, juridically, the presence of Law No. 32 of 2009 concerning Environmental Protection and Management (UU PPLH) is not only expected to be able to provide legal protection for citizens as human beneficiaries of the availability of the environment, but also provide legal protection for the environment itself.

However, the rapid population growth has been overcome by development and industrialization. Meanwhile, industrialization itself, in addition to meeting all the needs of human life, also has a negative impact on environmental pollution. These impacts not only worsen the welfare of human life and other living creatures, but also cause a chain process of environmental damage [2]. The problem is increasingly complex where many environmental crimes are committed by corporations, and the damage they cause is large-scale [3]. Even today's environmental damage can cause damage to future generations, so that future generations will actually get environmental problems as a result of environmental damage in the past. Thus, the environment itself must be viewed and managed for a sustainable life, so that it is not solely for development growth [4]. Therefore, the recovery of environmental damage must be a priority, considering that the victims of the damage are not only the human generation as the beneficiaries of the environment, but also the environmental ecosystem itself.

However, all enthusiasm, programs, policies and regulations related to environmental protection and management are not directly proportional to law enforcement. The facts show that law enforcement on environmental damage is still difficult to conduct, because of the difficulty of proving and determining the standard criteria for environmental damage [5]. Another thing that needs to be taken seriously is that in the end the spearhead of the problem lies in not placing the environment itself as a victim. This is because even though law enforcement has been successfully carried out against perpetrators of environmental crimes, it is still not oriented towards criminal sanctions in the form of restoring environmental damage. This harsh reality is based on data showing that in the 2010-2019 period, of which 8 cases, only one case was imposed with additional criminal sanctions for restoration of environmental damage to the convict [6].

The facts above show that even though legal instruments are used, they cannot provide legal protection against environmental damage itself. The effectiveness of the PPLH Law is again questioned in the provision of legal protection for environmental sustainability. Considering the various role holders involved, both the government, law enforcement officers, stakeholders, and the community in handling the environment have not been based on Green Victimology. The definition of green victimology as given by Rob White is that "...refers to the study of the social process and institutional responses pertaining to victims of environmental crime" [7]. Based on these limitations, green victimology is a study of the processes that occur and develop in society and includes responses from related institutions that have close relationships with issues related to victims of environmental crimes [8].

Based on the above, the formulation of the problem that will be analyzed and described in this article is what 
factors affect the protection of environmental damage in Indonesia that has not been based on the perspective of Green Victimology and how the legal protection of the environment in Indonesia from the perspective of Green Victimology.

\section{RESEARCH METHOD}

This research is qualitative research with a normative juridical approach. The problem approach used is conceptual and statutory. The type of data source is secondary data obtained through literature study and analyzed qualitatively.

\section{FINDINGS AND DISCUSSION}

\section{The factors that influence the protection of environmental damage in Indonesia have not been based on the perspective of Green Victimology}

The emergence of Green Victimology is inseparable from the development of the 21st century issue of "green" and environmental damage [8]. Referring to the opinion of Rob White, where the limit of victims of environmental victimization in green victimology is not only limited to humans but also includes non-humans, among others, animals, trees, and rivers which are all interwoven in the ecosystem. This is related to the perspective of eco-justice which includes environmental justice with human victims, ecological justice with victims outside of humans, especially the environment and plants and animals, and species justice with animals and plants as victims [9]. Based on this, in the perspective of Green Victimology, it has expanded the boundaries of victims to include nonhumans.

The basis for including the environment as a victim is an ecocentric view. In the view of ecocentrism, it can be said that an environmental crime occurs when there are human actions that can injure the natural environment, for example a river becomes non-functioning which results in the death of the ecosystem that exists in the area along the river flow [8]. Hon Justice Brian J Preston emphasized that humans are not the only victims of environmental crimes. The biosphere and non-human biota have intrinsic value regardless of their utilitarian or instrumental value to humans. When damaged by environmental crimes, the biosphere and non-human biota also become victims. The losses incurred can be assessed from an ecological perspective and does not need to be anthropocentric [10].

Proper protection of the natural environment can be based on the nature rights, both as subjects and objects that deserve to be protected, including respecting its intrinsic value so that humans are obligated to protect it [8]. However, the fact is that in Indonesia legal protection against environmental damage is not based on the nature rights itself. It can be described the factors that influence the protection of environmental damage in Indonesia that have not been based on the perspective of green victimology as follows.

First, from the aspect of the legal structure component, that the framework of law enforcement officials has not placed non-humans as victims of environmental crimes and the lack of knowledge of law enforcement officers regarding the concept of green victimology. This has implications for the tendency of law enforcement officers to wait for reports of victims, in this case humans as the affected and disadvantaged parties. This factor has also influenced the attitude of law enforcement officers in imposing criminal sanctions, where even though in Article 119 of the PPLH Law the judge can impose environmental restoration as an additional criminal sanction, this recovery sanction is still very rarely imposed. This means that law enforcement officials have ignored the environmental ecosystem as a victim and do not see that recovery is something that is urgently needed by the environment that has been damaged. This is evidenced by several data showing that of the 70 environmental criminal cases that were decided from 2002 to $2015,43 \%$ of the defendants were acquitted; $40 \%$ sentenced to probation, $13 \%$ defendants were sentenced to imprisonment and fines, $2 \%$ onslag van gewijsde (free from lawsuits); and $2 \%$ of the claims were rejected. This shows that recovery has not yet become the mainstream in environmental crimes. In fact, in the 2010-2019 period, out of 8 cases, only one case was imposed with additional criminal sanctions for recovering the convict [6]. Another factor is that there are still many law enforcement agencies that lack the ability to solve cases properly, which is also influenced by the difficulty of proving environmental crime cases [11].

Second, from the aspect of the legal substance component, regulations regarding the environment in Indonesia have not placed the environment as a victim. This can be seen in its formulation, namely Article 119 of the PPLH Law regarding corporate criminal responsibility does not place recovery as a principal criminal sanction, but only as an additional criminal sanction. In fact, the formulation of the phrase "judges can" in the case of imposing additional penalties actually makes judges not bound to impose additional criminal sanctions in the form of reparation, so there is no legal guarantee that remedial action will be imposed. In fact, corporations also contribute to large-scale environmental damage. Another thing is that the strict liability principle in the PPLH Law is only applied to certain environmental crimes. The formulation in the PPLH Law is also not yet oriented towards preventive legal protection. In fact, the formulation of environmental criminal sanctions in the Draft Criminal Code (RUU KUHP) is lighter, which tends to use alternative sanctions systems such as imprisonment or fines. On the other hand, Law no. 32 of 2009 using a cumulative system of imprisonment and fines simultaneously. Therefore, it is difficult for corporate members to be sentenced to imprisonment, so it is likely that fines will be applied more to violations committed by 
individuals and corporations. This further shows that in the future, from the aspect of legal substance, the environment has not become a victim.

Third, from the aspect of the legal structure component, that the perspective and attitude pattern of the government, law enforcement officers, and some of the community itself tend to tolerate small-scale environmental damage and only act if environmental damage has an impact on human life or the surrounding community. Here can be seen the existence of selfishness in coexistence with nature and other living things. The omission and permission of the people's small habits, such as burning garbage in their homes or their environment, increasingly indicates that there is no mindset on how future generations, both human and non-human, will bear the impact of today's small human habits.

\section{Legal protection of the environment in Indonesia from the perspective of Green Victimology}

Environmental damage may require remediation from generation to generation, and therefore, the burden and costs of remediation are transferred to future generations. For example, remediation of contaminated land and restoration of habitats for species, populations, and ecological communities are intergenerational burdens that are passed from present to future generations [10]. Therefore, environmental crime victims challenge the traditional victimology approach as they are often victimized collectively and can involve non-conventional victims [12]. Based on this, in the perspective of Green Victimology, environmental protection must also emphasize prevention, because it involves non-human victims, the environment, and future generations.

In response to this, it is necessary to take the view of Barda Nawawi Arief that protection of crime victims can be seen from two meanings: first, interpreted as "legal protection not to become victims of criminal acts". Second, interpreted as "protection to obtain legal guarantees/compensation for the suffering/loss of a person who has been a victim of a criminal act". The form can be in restoration of inner balance, restoration of good name (rehabilitation), the provision of compensation (compensation, restitution, social welfare security) [13]. Even though the concept of protection is intended for someone who is a victim, in environmental crimes it can also be applied to non-humans and the environment itself as a victim.

The first form of protection is preventive protection. This means emphasizing on prevention so as not to become a victim or prevent the occurrence of victims continuously. This is very appropriate in the context of environmental protection, where protection must also be oriented to ecosystem sustainability and future generations. Therefore, to ensure the existence of preventive protection, it must be supported from the aspect of legal substance, namely through the reconstruction of environmental legislation. In improving the PPLH Law, it is necessary to expand the concept of victims of environmental crimes to include non-humans, the environment, and future generations. On the other hand, it is necessary to expand the principle of strict liability in environmental crimes, and especially to place the restoration of environmental damage as the main criminal sanction and the implementation of a double track system on sanctions for recovery and other criminal sanctions. Preventive protection also needs to be carried out with an educational approach to the community, law enforcement officers, stakeholders, and even the ranks of the government itself regarding Green Victimology. This is because not all stakeholders know and understand the concept of Green Victimology, and it is not easy to change one's perspective in responding to environmental damage. This is as happened before, where in Indonesia it takes quite a long time to be able to apply the ideas of the Restorative Justice concept and its regulation in regulations. Therefore, education is the starting point to encourage changes in the concept of environmental protection based on Green Victimology. Another important thing is that the prevention of environmental damage is of course very dependent on a system of monitoring activities that have the potential to damage the environment at the community level. This is because there is a tendency for neglect and tolerant attitudes from authorized institutions and even among the communities themselves towards habitual patterns that cause smallscale pollution or damage, such as burning garbage, dumping household waste, and so on. Therefore, it is necessary to have a licensing and supervision system in every community and corporate activity that has the potential to pollute the environment, even though the potential is small.

Repressive protection is the action needed to reduce the suffering or loss of the victim. In relation to victims of environmental crimes, it is necessary to emphasize efforts to take action against damage through strengthening the synergy of law enforcement officers. Building synergy between law enforcement officers is very necessary, considering that the imposition of reparation sanctions for environmental damage begins with the same understanding, goals, and commitments among law enforcement officers in disclosing environmental crimes, collecting evidence, law enforcement, and imposing remediation sanctions.

\section{IV.CONCLUSION}

There are several factors that influence the protection of environmental damage in Indonesia that have not been based on the perspective of Green Victimology. From the aspect of the legal structure, namely the framework of law enforcement officials has not placed non-humans as victims of environmental crimes, so they tend to wait for reports of victims, in this case humans as affected parties and sanctions for recovery are very rarely imposed. From the aspect of legal substance, namely the formulation in the PPLH Law does not place recovery as the main 
criminal sanction and does not require judges to impose recovery as an additional criminal sanction, the strict liability principle in the PPLH Law is only applied to certain environmental crimes, and the formulation in the PPLH Law is not yet oriented towards on preventive legal protection. From the aspect of the legal structure component, it is the perspective and pattern of attitudes and habits of the government, law enforcement officers, and some of the people themselves who tend to tolerate small-scale environmental damage. Therefore, legal protection of the environment from the perspective of green victimology seeks to place the environment as a victim, so it is necessary to base it on two aspects of protection, namely preventive and repressive protection. Preventive protection emphasizes the prevention aspect so that an educational approach is needed, the existence of a system for monitoring potential activities at the community level, to the reconstruction of criminal law, namely the expansion of the principle of strict liability in environmental crimes and placing recovery as the main criminal sanction. Meanwhile, repressive protection emphasizes efforts to take action against damage through strengthening the synergy of law enforcement officers, which are oriented towards the recovery of environmental damage.

\section{REFERENCES}

[1] Prasetyo A.B., Saputra, Dauri dan Andreas, "Model Perlindungan dan Pengelolaan Lingkungan Hidup dalam Mewujudan Good Governance," Jurnal S A S I, Vol. 27, No. 1, 2021.

[2] Vania Zulfa1, Milson Max1, Iskar Hukum1, Irfan Ilyas, "Isu-Isu Kritis Lingkungan dan Perspektif Global," Jurnal Green Growth dan Manajemen Lingkungan, Vol. 5, No. 1, Juli 2016.

[3] Januari Siregar, Muaz Zul, "Penegakan Hukum Dalam Tindak Pidana Lingkungan Hidup di Indonesia," Mercatoria, Vol. 8, No. 2, Desember 2015.

[4] Erik Rahmanul Hakim, "Penegakan Hukum Lingkungan Indononesia Dalam Aspek Kepidanaan," Media Keadilan: Jurnal Ilmu Hukum, Vol. 11, No. 1, April 2020.

[5] Sutrisno, "Politik Hukum Perlindungan dan Pengelolaan Lingkungan Hidup," Jurnal Hukum, Vol. 18, No. 3, Juli 2011.

[6] Azam Hawari, Deni Daniel and Marysa Mutmainal Handayani, "Reorientasi Penegakan Hukum Pidana Lingkungan Hidup melalui Perjanjian Penangguhan Penuntutan," Jurnal Hukum Lingkungan Indonesia, Vol. 6, No. 1, 2019.

[7] Rob White, "Environmental Victimology and Ecological Justice," in Crime, Victims and Policy: International Contexts, Local Experiences, Basingstoke, Palgrave Macmillan, 2015

[8] Angkasa, Viktimologi, Jakarta: Raja Grafindo Persada, 2020.

[9] Rob White, "Green Victimology and Non-Human Victims," International Review of Victimology, Vol. 24, No. 2, February 2018.

[10] Hon Justice Brian J Preston, "The use of restorative justice for environmental Crime," Criminal Law Jurnal, Vol. 35, No.3, June 2011.

[11]Rani Hendriana, Nurani Ajeng Tri, Angkasa, "Law Enforcement of Environmental Pollution and Damage," in IOP Conf. Series: Earth and Environmental Science, 2020.

[12]Eileen Skinnider, "Victims of Environmental Crime - Mapping the Issues", Vancouver: The International Centre for Criminal Law Reform and Criminal Justice Policy, March 2011.

[13]Rani Hendriana, "The Problematics of Legal Protection Toward Victims of Domestic Physical Violence in Indonesia," in The 2nd International Conference of Law, Government and Social Justice (ICOLGAS), 2020. 